\begin{tabular}{|l|l|l||}
\hline \multicolumn{2}{|c|}{ PublisherInfo } \\
\hline \hline PublisherName & $:$ & BioMed Central \\
\hline \hline PublisherLocation & $:$ & London \\
\hline \hline PublisherImprintName & $:$ & BioMed Central \\
\hline \hline
\end{tabular}

\title{
Predicting global protein-protein interactions
}

\begin{tabular}{|l|l|l||}
\hline \multicolumn{2}{|c|}{ ArticleInfo } \\
\hline \hline ArticleID & $:$ & 3557 \\
\hline \hline ArticleDOI & $:$ & $10.1186 /$ gb-2000-1-1-reports023 \\
\hline \hline ArticleCitationID & $:$ & reports023 \\
\hline \hline ArticleSequenceNumber & $:$ & 48 \\
\hline \hline ArticleCategory & $:$ & Paper report \\
\hline ArticleFirstPage & $:$ & 1 \\
\hline \hline ArticleLastPage & $:$ & 3 \\
\hline \hline & & RegistrationDate : 2000-1-18 \\
ArticleHistory & $:$ & Received \\
\hline \hline ArticleCopyright & $:$ & BioMed Central Ltd2000-1-18 \\
\hline \hline ArticleGrants & $:$ & \\
\hline \hline ArticleContext & $:$ & 130591111 \\
\hline \hline
\end{tabular}




\section{Abstract}

Many protein-protein interactions are identified at once using high-throughput yeast two-hybrid screens.

\section{Significance and context}

The identification of large numbers of proteins from genomic sequence information is soon followed by the more difficult problem of finding out which proteins interact with each other. Walhout et al. attack this problem by exploiting the familiar yeast two-hybrid assay on a large scale. First they fuse each gene to be tested to either the DNA-binding domain or the activation domain of the transcription factor Gal4p. Then they express each pair of fusions in yeast. When two test proteins (A and B, say) interact, the two domains of Gal4p come together and cause transcription of a reporter gene. The novel aspect of their approach is the scale: Walhout et al. used a test set of 29 proteins known to be involved in vulval development in the nematode Caenorhabditis elegans. If the resulting pairs of interacting proteins are biologically meaningful, it's hoped that the method can be used for similar experiments on larger systems.

\section{Key results}

The authors tested proteins known to be involved in vulval development in C. elegans using the yeast two-hybrid assay for binding to each other and to proteins expressed from a C. elegans cDNA library. The result was a list of 124 pairs of predicted interactions involving the vulval development proteins. To see whether these interactions were meaningful, Walhout et al. first checked for mention of their pairs in the literature. Eleven pairs of interactions had been studied previously, of which Walhout et al. observed six. This means there is a significant rate of 'false negatives' (failure to recognize interactions that occur in vivo) in their system. Next the authors compared the sequences of proteins in their study to those of proteins in other organisms. They find seven pairs that are homologous to interacting pairs of proteins in yeast, humans and other organisms. Lastly, the authors try to interpret their whole body of pairwise data by finding clusters - cases in which protein $\mathrm{A}$ binds to protein $\mathrm{B}, \mathrm{B}$ binds to $\mathrm{C}$, and so on to $\mathrm{X}$, where $\mathrm{X}$ binds to A. They argue that pairs in such clusters are less likely than other pairs in their data to be artifacts of the two-hybrid assay. They describe one cluster involving the LIN family of developmentally important proteins. 


\section{Methodological innovations}

There is a lot of new biotechnology in this paper. The authors describe a new strategy that moves genes into vectors the way organisms swap genes into and out of chromosomes - via recombination. They also mention (but do not describe in detail) a new two-hybrid system that uses three reporter genes for increased sensitivity. And in their two-hybrid experiments, instead of cotransfecting one yeast with the genes for both A and B, they mate one yeast carrying A with another yeast carrying B.

\section{Reporter's comments}

The main strength of this paper is the biotechnology and the fact that the authors have provided a new list of hypotheses for biochemists to test. But it would be nice to see more analysis of the data. The idea of detecting A, B, ... X clusters is interesting, although the authors do not explain exactly what to do with these clusters. They might be useful, for example, when plugged into genetic networks.

\section{Table of links}

Science

\section{References}

1. Walhout AJM, Sordella R, Lu X, Hartley JL, Temple GF, Brasch MA, Thierry-Mieg N, Vidal M:

Protein interaction mapping in C. elegans using proteins involved in vulval development. Science. 2000, 287: 116-122. 0036-8075 